\title{
Clinicopathological study of anemia during pregnancy
}

\author{
Sarojamma C., R. Atchutha Subiksha*
}

Department of Obstetrics and Gynecology, Rajarajeswari Medical College and Hospital, Kambipura, Bangalore, Karnataka, India

Received: 11 February 2020

Accepted: 03 March 2020

*Correspondence:

Dr. R. Atchutha Subiksha,

E-mail: ratchutha@gmail.com

Copyright: (C) the author(s), publisher and licensee Medip Academy. This is an open-access article distributed under the terms of the Creative Commons Attribution Non-Commercial License, which permits unrestricted non-commercial use, distribution, and reproduction in any medium, provided the original work is properly cited.

\section{ABSTRACT}

Background: In developing countries the prevalence of anemia among pregnant women averages $60 \%$ resulting in varying levels of adverse pregnancy outcomes. Iron, Vitamin B12 and folic acid deficiencies, malaria, intestinal parasitic infections and hemoglobinopathies are the principal causes of anemia in pregnancy. Above nutritional requirements increase during pregnancy and if it is not maintained, may result in adverse maternal and fetal outcomes. The aim of this study was to study the prevalence of anemia in pregnant mothers, study the clinical patterns of anemia in pregnancy and to study the histopathological patterns of anemia during pregnancy.

Methods: This is a prospective study done on 60 pregnant women whose hemoglobin level is less than $10.9 \mathrm{gm} / \mathrm{dL}$. Blood samples were taken, and peripheral blood smears were examined along with their complete clinical and obstetric history.

Results: Out of 60 cases of anemia, $40 \%$ were found to have dimorphic anemia, 30\% with microscopic hypochromic anemia, $20 \%$ of patients have normocytic hypochromic anemia, $1.7 \%$ had sickle-cell anemia and $8.3 \%$ of patients were thalassemia cases. The risk factors for anemia in this study is noted to be low social economic status, occurrence of complications during previous pregnancy and multiparty. In this study anemia was more commonly found in the multigravida women and in the third trimester of pregnancy.

Conclusions: With improved social economic conditions, early detection, good antenatal care, awareness regarding available treatment, a healthy diet, routine antenatal counselling and adequate iron supplementation, anemia in pregnancy can be avoided.

Keywords: Anemia in pregnancy, Antenatal hemoglobin level, Morphological patterns

\section{INTRODUCTION}

Anemia is the most common pregnancy complication noted on a daily basis, in India. The complications of anemia may result in adverse pregnancy outcomes ranging from mild to severe forms.

In India the prevalence of anemia among pregnant women ranges from $65 \%$ to $75 \%$, according to the WHO. ${ }^{1,2}$ As many as 4 to $16 \%$ of maternal deaths are due to anemia, in India. ${ }^{3}$ A haemoglobin concentration below $11 \mathrm{~g} / \mathrm{dL}$ or packed cell volume of less than $33 \%$ is considered as anemia during pregnancy by WHO.
According to centre for Disease Control and Prevention, it is defined as haemoglobin or haematocrit value less than fifth percentile of distribution of haemoglobin or haematocrit in a healthy reference population of pregnant women.

Expert group on Indian Council of Medical Research has concluded that anaemia in pregnancy can be classified into mild anaemia 10-10.9 $\mathrm{g} / \mathrm{dl}$, moderate anaemia 7-9.9 $\mathrm{g} / \mathrm{dl}$, severe 4-6.9 g/dl and very severe $<4 \mathrm{~g} / \mathrm{dl}$.

In developing countries, the prevalence of anaemia among pregnant women averages $60 \%$ (in India) ranging 
between $35 \%$ to $100 \%$ among different regions of the world resulting in varying levels of adverse pregnancy outcomes. It occurs in $40 \%$ to $80 \%$ of pregnant woman. Iron and folic acid deficiency, malaria, intestinal parasitic infections and haemoglobinopathies are the principal causes of anaemia in pregnancy. Iron requirements increase during pregnancy and if it is not maintained, may result in adverse maternal and fetal outcomes.

The aim of this study is to study the prevalence of anemia in pregnant mothers, study the clinical patterns of anemia in pregnancy and to study the histopathological patterns of anemia during pregnancy.

\section{METHODS}

This study is a prospective study done over a period of one year from February 2018 to January 2019, done in department of obstetrics and gynecology, Raja Rajeswari Medical College and Hospital, Bangalore, Karnataka, India.

\section{Inclusion criteria}

- This study was conducted on 60 pregnant women whose hemoglobin level is less than $10 \mathrm{~g} / \mathrm{dL}$.

\section{Exclusion criteria}

- Multi fetal gestation, previous correction of anemia including recent blood transfusion history.

Complete clinical and obstetric history was recorded. Socio economic status and routine diet was noted. Peripheral blood smear was prepared from patient's blood sample and stained by Leishman's stain, fixed with fixative and observed under low power of microscope and findings noted. Sickle cell test was done by using freshly prepared $2 \%$ sodium metabisulphite solution and RBCs observed under both low and high-power microscope for evidence of sickle shaped cells. Samples obtained from clinically diagnosed Thalassemia patients were sent for hemoglobin electrophoresis for confirmatory diagnosis of Thalassemia.

\section{RESULTS}

Table 1: Age distribution.

\begin{tabular}{|l|l|l|}
\hline Age in years & Number of patients & $\%$ \\
\hline $18-20$ & 4 & $6.7 \%$ \\
\hline $21-25$ & 22 & $36.7 \%$ \\
\hline $26-30$ & 29 & $48.3 \%$ \\
\hline $31-35$ & 5 & $8.3 \%$ \\
\hline Total & 60 & 100 \\
\hline
\end{tabular}

Total 60 cases were studied. Maximum number of cases were seen in the age group of 26 to 30 years of age (Table 1).
Most of the patients presenting with anemia were lower middle- and lower-class population in our study population (Table 2).

Table 2: Socioeconomic distribution.

\begin{tabular}{|c|c|c|}
\hline $\begin{array}{l}\text { Socioeconomic status } \\
\text { (modified Kuppuswamy) }\end{array}$ & $\begin{array}{l}\text { Number of } \\
\text { patients }\end{array}$ & $\%$ \\
\hline Upper class & 6 & $10 \%$ \\
\hline Upper middle class & 9 & $15 \%$ \\
\hline Lower middle class & 19 & $31.6 \%$ \\
\hline Upper lower class & 15 & $25 \%$ \\
\hline Lower class & 11 & $18.3 \%$ \\
\hline Total & 60 & 100 \\
\hline
\end{tabular}

Out of 60 cases, 40 percent were found to have dimorphic anemia, 30 percent microscopic hypochromic anemia, 20 percent normocytic normochromic anemia, 8.3 percent were thalassaemia cases and 1.7 percent sickle-cell anemia (Table 3).

Table 3: Distribution based on red cell morphology.

\begin{tabular}{|l|l|l|}
\hline Peripheral smear & $\begin{array}{l}\text { Number of } \\
\text { patients }\end{array}$ & $\%$ \\
\hline Dimorphic anemia & 24 & $40 \%$ \\
\hline Microcytic hypochromic anemia & 18 & $30 \%$ \\
\hline Normocytic normochromic aner & 12 & $20 \%$ \\
\hline Thalassemia & 5 & $8.3 \%$ \\
\hline Sickle cell anemia & 1 & $1.7 \%$ \\
\hline Total & 60 & $100 \%$ \\
\hline
\end{tabular}

Table 4: Distribution based on obstetric score.

\begin{tabular}{|l|ll|}
\hline Obstetric index & Number of patients & $\%$ \\
\hline Gravida & & \\
\hline I & 27 & $45 \%$ \\
\hline II & 24 & $40 \%$ \\
\hline III & 6 & $10 \%$ \\
\hline IV & 3 & $5 \%$ \\
\hline Total & 60 & $100 \%$ \\
\hline
\end{tabular}

A total 27 cases were primigravidae and remaining cases were multigravida (Table 4). 9 cases were diagnosed in the first trimester, 18 cases noted in second trimester and 33 cases in the last trimester (Table 5).

Table 5: Trimester wise distribution.

\begin{tabular}{|lll|}
\hline Trimester & Number of patients & $\%$ \\
\hline I & 9 & $15 \%$ \\
\hline II & 18 & $30 \%$ \\
\hline III & 33 & $55 \%$ \\
\hline Total & 60 & $100 \%$ \\
\hline
\end{tabular}

A total $15 \%$ of cases had mild anemia, whereas $55 \%$ of cases had moderate anemia and 30\% had severe anemia (Table 6). 
Table 6: Grading of anemia based on ICMR classification.

\begin{tabular}{|lll|}
\hline $\begin{array}{l}\text { Grade of Anemia } \\
\text { (ICMR classification) }\end{array}$ & $\begin{array}{l}\text { Number of } \\
\text { patients }\end{array}$ & $\%$ \\
\hline Very severe $<4 \mathrm{~g} / \mathrm{dL}$ & - & - \\
\hline Severe $(4-6.9 \mathrm{~g} / \mathrm{dL})$ & 9 & $15 \%$ \\
\hline Moderate $(7-9.9 \mathrm{~g} / \mathrm{dL})$ & 33 & $55 \%$ \\
\hline Mild $(1--10.9 \mathrm{~g} / \mathrm{dL})$ & 18 & $30 \%$ \\
\hline Total & 60 & $100 \%$ \\
\hline
\end{tabular}

\section{DISCUSSION}

In the past few decades, in all developing countries anemia in pregnancy constitutes a major public health problem. ${ }^{4,5}$ Prichard and Scott who measured the hemoglobin and hematocrit concentration in a large group of healthy young woman found that there is a $5 \%$ fall of hematocrit for every pregnancy which starts at 8 to 10 weeks and reaches a maximum during the second trimester. This is mainly due to intravascular volume expansion. Nearly $50 \%$ of the pregnant women in the world are said to be anemic, compared to $23 \%$ in industrialized countries. ${ }^{4,6}$ The prevalence of anemia is higher in pregnancy due to an increase of almost $50 \%$ of blood volume.

Table 7: Comparison of age distribution.

\begin{tabular}{|lllll|}
\hline Authors & $\mathbf{1 8 - 2 0}$ & $\mathbf{2 1 - 2 5}$ & $\mathbf{2 6 - 3 0}$ & $\mathbf{3 1 - 3 5}$ \\
\hline Ahmed L & $\mathbf{4 5 . 8 \%}$ & $30.9 \%$ & $20.9 \%$ & $2.36 \%$ \\
\hline Haniff J et al & $4.29 \%$ & $53.6 \%$ & $37.9 \%$ & $4.2 \%$ \\
\hline Present study & $\mathbf{6 . 7 \%}$ & $36.7 \%$ & $48.3 \%$ & $8.3 \%$ \\
\hline
\end{tabular}

Table 8: Comparison of trimester wise distribution.

\begin{tabular}{|lll|l|}
\hline Authors & $\begin{array}{l}\text { I } \\
\text { Trimester }\end{array}$ & $\begin{array}{l}\text { II } \\
\text { trimester }\end{array}$ & $\begin{array}{l}\text { III } \\
\text { trimester }\end{array}$ \\
\hline $\begin{array}{l}\text { Rasheed P, et } \\
\text { al }\end{array}$ & $27.7 \%$ & $37.3 \%$ & $50.2 \%$ \\
\hline Present study & $15 \%$ & $30 \%$ & $55 \%$ \\
\hline
\end{tabular}

Table 9: Comparison of obstetric score.

\begin{tabular}{|lll|l|}
\hline Authors & G1 & G2-G3 & G4 \\
\hline Haniff J et al & $27.42 \%$ & $62.77 \%$ & $9.79 \%$ \\
\hline Present study & $45 \%$ & $50 \%$ & $5 \%$ \\
\hline
\end{tabular}

In this present study maximum number of cases were observed between 21-30 years, constituting 85\% which correlates to observations made by Ahmad $\mathrm{N}$ and Haneef $\mathrm{J}$ (Table 7). ${ }^{1,4}$ Advanced period of gestation increases the risk of anemia. In present study maximum number of cases were observed in third trimester and correlates with Rasheed P et al (Table 8). ${ }^{6}$ In this study it was found that $45 \%$ primigravidae, $50 \%$ were noted to be second or third gravida and $5 \%$ were in their $4^{\text {th }}$ pregnancy, similar to studies done by Hanif $\mathrm{J}$ et al (Table 9). ${ }^{4}$ Majority of the cases showed moderate anemia corresponding to the study is done by Ahmad $\mathrm{N}$ et al (Table 10). ${ }^{1}$
Table 10: Comparison based on severity of anemia (ICMR classification).

\begin{tabular}{|ll|l|l|}
\hline Authors & $\begin{array}{l}\text { Mild } \\
\text { anemia }\end{array}$ & $\begin{array}{l}\text { Moderate } \\
\text { anemia }\end{array}$ & $\begin{array}{l}\text { Severe } \\
\text { anemia }\end{array}$ \\
\hline Ahmed L et al & $30.17 \%$ & $50.9 \%$ & $18.9 \%$ \\
\hline Present study & $30 \%$ & $55 \%$ & $15 \%$ \\
\hline
\end{tabular}

The common symptoms presented by pregnant women with anemia were fatigue, pallor, dyspnea, paresthesia and bilateral pedal edema. Among these majority of the cases hand pallor on examination followed by fatigue and dyspnea. Some cases present and with pre-eclampsia and previous history of abortions. A few cases of beta thalassemia diagnosed clinically for the first time in pregnancy were noted and suitable blood tests were done to confirm the diagnosis, whereas other cases of thalassemia were diagnosed prior to conception and treated accordingly.

The commonest red blood cell pictures among the patients studied were dimorphic anemia and a microcytic hypochromic anemia (Table 3). The most common duration of anemia was in the third trimester (Table 5) and the most common clinical type of anemia was iron deficiency anemia. After the first trimester of pregnancy there is an increase in the demand by the fetus and it is combined with the hemodilution effect of pregnancy resulting in anemia in the third trimester. In India, being a tropical country iron is lost through sweat and also by infestation by parasites. Other factors such as adequacy of vitamin B12 and folic acid also influence the hematopoietic status of an individual as proved in dimorphic blood picture.

\section{CONCLUSION}

Anemia in pregnancy is highly prevalent in India and the commonest morphological patterns of anemia in this study are dimorphic anemia, mostly noted in the lower socioeconomic groups, multiparous women with poor diet and inadequate antenatal check-ups. Thus, the necessity of necessity of implementation of nationwide nutritional welfare programs, pre-conceptional counselling, early ante-natal diagnosis of the patient are important factors in preventing anemia in pregnancy and more importantly its maternal and fetal adverse effects.

Funding: No funding sources Conflict of interest: None declared

Ethical approval: The study was approved by the Institutional Ethics Committee

\section{REFERENCES}

1. Ahmad N, Kalakoti P, Bano R, Arif SMM. The prevalence of anemia and associated factors in pregnant women in a rural Indian community. Aus Med J. 2010;3(5):276-80. 
2. Sidhu GS, Sood SK, Swami RV. Anemia of pregnancy in northern India, Delhi area. Indian $\mathrm{J}$ Med. 1988;55(6):449-57.

3. Bivalkar NY, Wingkar KC, Joshi AG, Jagtap S. Study of anemia and it's epidemiological determinants in pregnant women. Inter $\mathrm{J}$ Healthcare Biomed Res. 2015;3(2):140-5.

4. Haniff J, Das A, Onn LT, Sun CW, Nordin NM, Rampal S, et al. Anemia in pregnancy in Malaysia: a cross se toi all survey. Asia PAC J Cinnutr. 2007;16(3):527-36

5. Yalwagwarzo M, Guwahati EA. The pattern of anemia in northern Nigerian pregnant women. J Med Med Sci. 2013;4(8):319-23.
6. Koura MR, Makki SM. Anemia in pregnancy. A study among attendees of PHC. Ann Saudi Med. 2008;28(6):449-52.

7. Anjum A, Manzoor N, Shakir HA. Prevalence of anemia during pregnancy in district Faisalabad, Pakistan. University J Zool. 2015;30(1):15-20.

Cite this article as: Sarojamma C, Atchutha $\mathrm{S}$. Clinicopathological study of anemia during pregnancy. Int J Reprod Contracept Obstet Gynecol 2020;9:1545-8. 